\title{
Effect of Superabsorbent Polymer on Seedling Emergence and Growth of Cotton under Water Stress Conditions
}

\author{
Panayiota PAPASTYLIANOU*, Angeliki KOUSTA \\ Agricultural University of Athens, School of Plant Sciences, Department of Crop Science, Laboratory of \\ Agronomy, 75 Iera Odos St., 11855 Athens, Greece \\ *corresponding author: ppapastyl@aua.gr
}

BulletinUASVM Horticulture 77(1) / 2020

Print ISSN 1843-5254, Electronic ISSN 1843-5394

DOI:10.15835/buasvmcn-hort: 2020.0011

\begin{abstract}
Water availability is one of the major limiting factors of cotton productivity. The soil application of superabsorbent polymers (SAPs) may increase water use efficiency, improve soil physical properties, enhance seed germination and emergence, crop growth and yield and reduce the irrigation requirements of plants. The objective of this study was to investigate the effect of Zeba ${ }^{\circledR}$, a polymer based on corn starch, on seedling emergence and growth of cotton under water stress. A set of pot experiments was conducted under completely randomized design with four replications of 25 seeds. Treatments included application rates of 5, 10, 15, $20 \mathrm{~kg} / \mathrm{ha}$ and an untreated control, all under three levels of irrigation (adequate, moderate and deficit). The emergence performance was evaluated by final emergence percentage and mean emergence time. Root and shoot growth were measured for length and weight. The application of Zeba ${ }^{\circledR}$ promoted seedling emergence (higher emergence percentage from 17.9 to $22.6 \%$ and lower mean emergence time from 36 to $46 \%$ compared to control). Higher values for root and shoot traits were observed under Z10 and Z15 rates regardless of irrigation treatments. The adoption of the proposed SAP could represent a promising solution and thus increase moisture conservation in cotton.
\end{abstract}

Keywords: Gossypium hirsutum, SAP, seedling emergence, water stress, Zeba ${ }^{\circledR}$

\section{Introduction}

Cotton (Gossypium hirsutum L.) is one of the most important fiber-producing plants. In addition, cottonseed is used for livestock feed and for cotton oil extraction. The cultivation of cotton has high economic value and is important in semi-arid areas where it represents a significant source of income for large and small-scale farmers. Greece is the leading cotton-growing country in the European Union, with the crop being cultivated on approximately 280,000 ha (13\% of arable land) producing $300,000 \mathrm{t}$ or $1.2 \%$ of global lint cotton annually (FAOSTAT,
2018). Approximately 100,000 rural and 80,000 urban families are involved in the cultivation and processing of cotton, showing the economic and social importance of this crop to the Greek economy (Papastylianou and Argyrokastritis, 2014). In ecologically marginal regions for cotton production, like Greece, successful commercial yields are often constrained by a short growing season. A common cultural practice for expanding the short growing season is early planting. However, low temperatures and, in areas where precipitation is low and erratic, water stress are major factors affecting cotton establishment and 
crop success (Papastylianou and Karamanos, 2012; Papastylianou and Argyrokastritis, 2014; Tsaliki et al., 2019).

Superabsorbent Polymers (SAPs) are threedimensional, cross-linked hydrophilic polymers that form hydrogels when moistened. They are able to absorb large amounts of water, even up to 500 times their original size and weight, within a short period of time and release it slowly under drought conditions. The soil application of SAP may effectively increase water use efficiency, improve soil physical properties, enhance seed germination and emergence, crop growth and yield and reduce the irrigation requirements of plants (Guilherme, et al., 2015; Kumar et al., 2018). SAPs are classified as natural polymers, derived from polysaccharides or polypeptides and synthetic polymers based on petrochemical substrate. Although the majority of SAPs are manufactured from synthetic polymers, mainly from acrylic acid, its salts and acrylamide, due to their superior price-to-efficiency balance there is recently a tendency towards use of natural polymers. Among them, carbohydrate polymers (polysaccharides) such as chitin, cellulose, starch and natural gums (xanthan, guar and alginates) are low cost, abundant, available and renewable organic materials (Guilhermeetal.,2018; Nnadiand Brave, 2011; Ranganathan et al., 2018; ZohuriaanMehr and Kabiri 2008). In particular, the positive effects of carbohydrate polymers application on germination and crop establishment, growth, yield and water use efficiency were reported for many crops under arid and semi-arid conditions ( $\mathrm{Li}$ et al., 2014, wheat; Serena et al., 2012, turfgrass; Tao et al., 2018, corn; Yazdani et al., 2007, soybean). The effectiveness of a particular SAP depends on its physical and chemical characteristics, the rate of application as well as the soil properties and water status (Zohuriaan-Mehr and Kabiri 2008). In Greece, the use of SAPs is still limited. In addition, less is known about cotton responses cultivated in soils amended with superabsorbent hydrogels. Therefore, the objective of this study was to investigate the effect of a biodegradable superabsorbent polymer based on natural corn starch $\left(Z^{2} \mathrm{eba}^{\circledR}\right)$ on seedling emergence and growth of cotton under limited water availability.

\section{Materials and Methods}

A set of pot experiments was carried out with a commercial cotton cultivar (Gossypium hirsutum cv. Lider) in a factorial design $5 \times 3$ laid out in randomized complete blocks with four replications. Treatments included Zeba ${ }^{\circledR}$ application rates of 5, $10,15,20 \mathrm{~kg} / \mathrm{ha}$ and an untreated control (Z5, Z10, $\mathrm{Z15}, \mathrm{Z} 20$ and Z0), all under three levels of irrigation (adequate, moderate and deficit) forming a total of 15 treatment combinations. Each combination consisted of five pots replicated four times, so 300 pots in total were used in this experiment. The superabsorbent polymer (hydrogel) Zeba ${ }^{\circledR}$ is formed by hydrolyzed starch-polyacrylonile graft copolymers. It is a biodegradable, highly absorbent, water insoluble hydrogel, swelling up to 400 times its original weight and slowly releasing the captured moisture to plant roots in response to capillary action of the root hairs (Chiorescu et al., 2017). Seeds were surface sterilized in a $1 \%$ sodium hypochlorite solution, rinsed in distilled water and dried before the experiment. Each treatment combination consisted of 25 seeds arranged in five round plastic pots (of $25 \mathrm{~cm}$ diameter and $20 \mathrm{~cm}$ height, with a filter paper placed at the bottom above small holes). The pots were filled with field soil after previously being airdried, ground and passed through a $2 \mathrm{~mm}$ sieve, collected from $25 \mathrm{~cm}$ depth at the experimental farm of the Agricultural University of Athens. The soil was clay loam $(29.3 \%$ clay, $33.8 \%$ silt and $36.9 \%$ sand) with $\mathrm{pH} 7.17,1.17 \%$ organic matter, $13.4 \%$ nitrogen content, sufficient levels of nitrate, moderate in available phosphorus and rich in available potassium and sodium $\left(104.3 \mathrm{NO}_{3}^{-}, 9.95\right.$ P, $590 \mathrm{~K}$ and $110 \mathrm{Na}$ ppm, respectively). Zeba ${ }^{\circledR}$ superabsorbent polymer (granular) was placed at $5 \mathrm{~cm}$ depth and five seeds per pot were sown for each hydrogel level and irrigation treatment, giving a total of 375 seeds per replication. For the non-stressed water regime (adequate irrigation), pots were maintained at field capacity throughout the experimental period by irrigating four times a week with $0.001 \mathrm{~cm}^{3}$ of water per pot. In the moderate and deficit treatments, irrigation water was applied at the rate of $75 \%$ and $50 \%$ of full irrigated treatment on the same day. The pots were placed in a growth chamber at a constant temperature of $25 \pm 2{ }^{\circ} \mathrm{C}$ under fluorescent light providing a photosynthetic photon flux density of $700 \mu \mathrm{mol} \mathrm{m}^{-2} \mathrm{~s}^{-1}$ for $16 \mathrm{~h} \mathrm{~d}^{-1}$.

Emergence counts were made daily. The experiment was completed 20 days after sowing (DAS). Root and shoot growth were measured for 
length and fresh weight. At the end of the tests the final percentage of emergence was calculated. Using the daily counts, the mean emergence time (MET) was calculated for each pot using the formula cited by Ellis and Roberts (1980).

$$
\mathrm{MET}=\sum \mathrm{n} \cdot \mathrm{D} / \sum \mathrm{n}
$$

where $\mathrm{n}=$ number of seeds newly emerged at time

$\mathrm{D}$; $\mathrm{D}=$ days from the beginning of the test, $\sum \mathrm{n}=$ final emergence.

Data of the final emergence percentage (arcsine transformed), mean emergence time, root and shoot length and weight were statistically analyzed by a completely randomized two-way analysis of variance (ANOVA) using the StatSoft software (1999). The analysis of variance was conducted considering SAP concentration and irrigations as fixed factors. When ' $\mathrm{F}$ ' ratios were significant, means were separated by the StudentNewman-Keuls (SNK) test at $\leq 0.05$.

\section{Results and Discussion}

Results of cotton emergence indices under optimal thermal conditions $\left(25^{\circ} \mathrm{C}\right)$ are shown in Figures 1 and 2 . The combined analysis of variance revealed that the rate of seedling emergence and mean emergence time were significantly affected by different application rates of SAP and irrigation levels $(P<0.001)$ (Tab. 1).

In particular, it was observed that the highest emergence percentage and the lowest mean emergence time were achieved in Z20 under all irrigation treatments. $\mathrm{Zeba}^{\circledR}$ application doses increased emergence percentage by $17.9,19.6$, 20.4 and $22.6 \%$ in case of rates Z5, Z10, Z15 and Z20 respectively, in comparison to control regardless of irrigation treatments (Fig. 1)

Different capital letters denote significant differences between irrigation treatments under the same SAP application rate $(P<0.05)$. Different lower-case letters denote significant differences between SAP treatments in the same irrigation level $(P<0.05)$. Vertical bars indicate the standard errors of the means.

Final emergence percentage ranged from 78 to $100 \%$ or $97 \%$ under adequate and moderate irrigation, respectively compared to the deficit irrigation (72 to $97 \%)$. $\mathrm{Zeba}^{\circledR}$ application rates reduced mean emergence time from 36 to $46 \%$ compared to control. Under deficit irrigation, the mean emergence time exceeded that under moderate irrigation by $25 \%$ and that under adequate irrigation by $34 \%$ (Fig. 2). The interaction effect of SAP doses and irrigation levels was significant on mean emergence time $(P<0.001)$ (Tab. 1). Similar positive effects of

Table 1. Combined analysis of variance (Anova) for different application rates of Zeba ${ }^{\circledR}$ (ZAR) and irrigation levels (IR) on final emergence percentage, mean emergence time, root and shoot length and weight of cotton seedlings at $25^{\circ} \mathrm{C}$.

\begin{tabular}{lcccc}
\hline & & Seedling emergence (\%) & Root length (cm) & Shoot length (cm) \\
\hline Source & df & $\mathrm{F}$ & $\mathrm{F}$ & $\mathrm{F}$ \\
\hline ZAR & 4 & $5.24^{* *}$ & $18.8^{* * *}$ & $27.6^{* * *}$ \\
\hline IR & $20.7^{* * *}$ & $13.5^{* * *}$ & $36.0^{* * *}$ \\
\hline ZAR $\times$ IR & 8 & $0.37^{\text {ns }}$ & $2.22^{*}$ & $0.87^{\text {ns }}$ \\
\hline & & Mean emergence time (day) & Root fresh weight $(\mathrm{g})$ & Shoot fresh weight (g) \\
\hline Source & $\mathrm{df}$ & $\mathrm{F}$ & $\mathrm{F}$ & $\mathrm{F}$ \\
\hline ZAR & 4 & $205.1^{* * *}$ & $14.5^{* * *}$ & $58.6^{* * *}$ \\
\hline IR & 2 & $179.9^{* * *}$ & $21.2^{* * *}$ & $13.9^{* * *}$ \\
\hline ZAR $\times$ IR & 8 & $5.04^{* * *}$ & $3.54^{* *}$ & $2.17^{*}$ \\
\hline
\end{tabular}

${ }^{*} P<0.05,{ }^{* *} P<0.01,{ }^{* * *} P<0.001 ;$ ns - not significant 


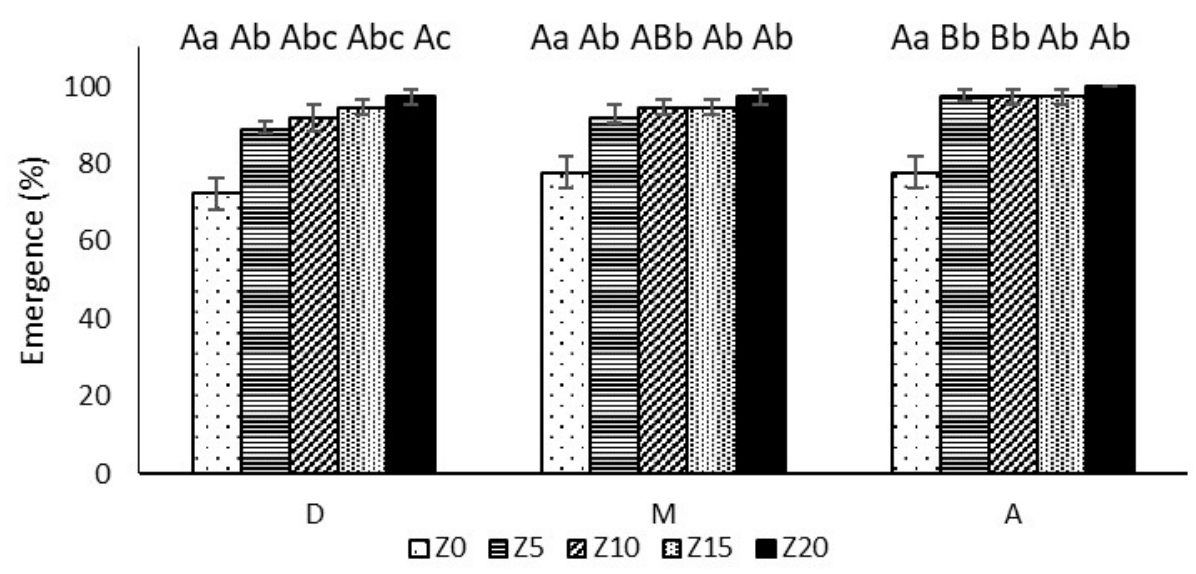

Figure 1. Emergence percentage of cotton seedlings under different SAP rates (Z0, untreated control; Z5, Z10, $\mathrm{Z15}, \mathrm{Z20}$, SAP application rates of 5, 10, 15, $20 \mathrm{~kg} /$ ha respectively) and irrigation treatments

(D - deficit; M - moderate; A - adequate irrigation).

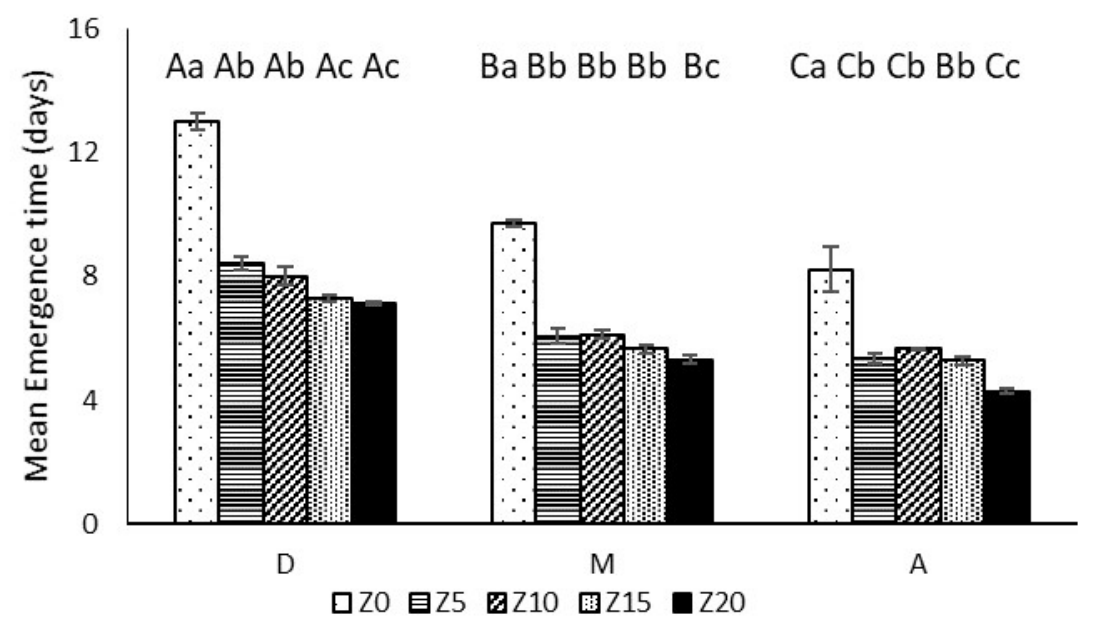

Figure 2. Mean emergence time of cotton seedlings under different SAP rates and irrigation treatments (SAP rates $\mathrm{Z0}, \mathrm{Z5}, \mathrm{Z10}, \mathrm{Z15}, \mathrm{Z} 20$ and irrigation levels D, M and A are as defined in Fig. 1)

hydrogel, incorporation with soil, more notable under limited irrigation, on increasing seedling emergence were reported in previous studies (Akhter et al., 2004; Rasanzali et al., 2019; Tao et al., 2018) under field and laboratory conditions. In addition, as reported by other studies the use of the superabsorbent polymer $\mathrm{Zeba}^{\circledR}$ in the cotton seed germination zone prior to sowing might reduce soil surface evaporation, maintaining soil moisture for longer periods of time and thus improving germination and crop establishment (Cranmer et al., 2009 and Bordovski et al., 2012).

Different capital letters denote significant differences between irrigation treatments under the same SAP application rate $(P<0.05)$. Different lower-case letters denote significant differences between SAP treatments in the same irrigation level $(P<0.05)$. Vertical bars indicate the standard errors of the means.

Concerning root and shoot growth, the effect of different application rates of SAP and irrigation levels were found to be statistically significant $(P<$ 0.001 ) and the interaction effects were significant on most of the of the seedlings' growth traits (Tab. 1). In general, root and shoot length and fresh weight decreased with the decreasing amount of $\mathrm{Zeba}^{\circledR}$ and increasing water stress. The root length and root fresh weight of the seedlings treated 
with SAP increased significantly from 10 to $42 \%$ and from 35 to $60 \%$ respectively, compared to the controls with the highest increments under deficit and moderate irrigation (Figs. $3 \mathrm{a}$ and $3 \mathrm{~b}$ ). Differences in shoot growth, namely length and fresh weight, were shown in Figure $4 a$ and $b$ respectively. In particular, it was observed that the lowest values were found in the controls where no hydrogel was added. SAP application also resulted in a significant enhancement of shoot growth but to a lesser extent than root elongation and root fresh weight, especially under deficit irrigation. In most cases, higher values for root and shoot growth were observed under Z10 and Z15 rates regardless of irrigation treatments (Figs. 3 and 4).

Different capital letters denote significant differences between irrigation treatments under the same SAP application rate $(P<0.05)$. Different lower-case letters denote significant differences between SAP treatments in the same irrigation level $(P<0.05)$. Vertical bars indicate the standard errors of the means.

Different capital letters denote significant differences between irrigation treatments under the same SAP application rate $(P<0.05)$. Different lower-case letters denote significant differences between SAP treatments in the same irrigation level $(P<0.05)$. Vertical bars indicate the standard errors of the means.

In similar studies on wheat and barley (Akhter et al., 2004), corn (Mazen et al., 2015) and soybean (Yazdani et al., 2007) the application of SAP resulted in significant increase of shoot and root traits by increasing the concentration of the polymers used. Furthermore, the positive effect of SAP levels on plant growth was more pronounced under limited water availability (Eneji et al., 2013; Fallahi et al., 2015). Moreover, Ngobeni et al. (2007) and Vizitiu et al. (2012) showed that addition of Zeba $^{\circledR}$ into the soil, especially at $15-20 \mathrm{~cm}$ depth, increased available water capacity, leading to optimal conditions for plant growth and development in terms of water supply. Seed germination and seedling development are critical stages in early growth and establishment of crops. The successful establishment of plants depends on moisture availability and is often restricted by limited soil water content particularly in arid and semi-arid
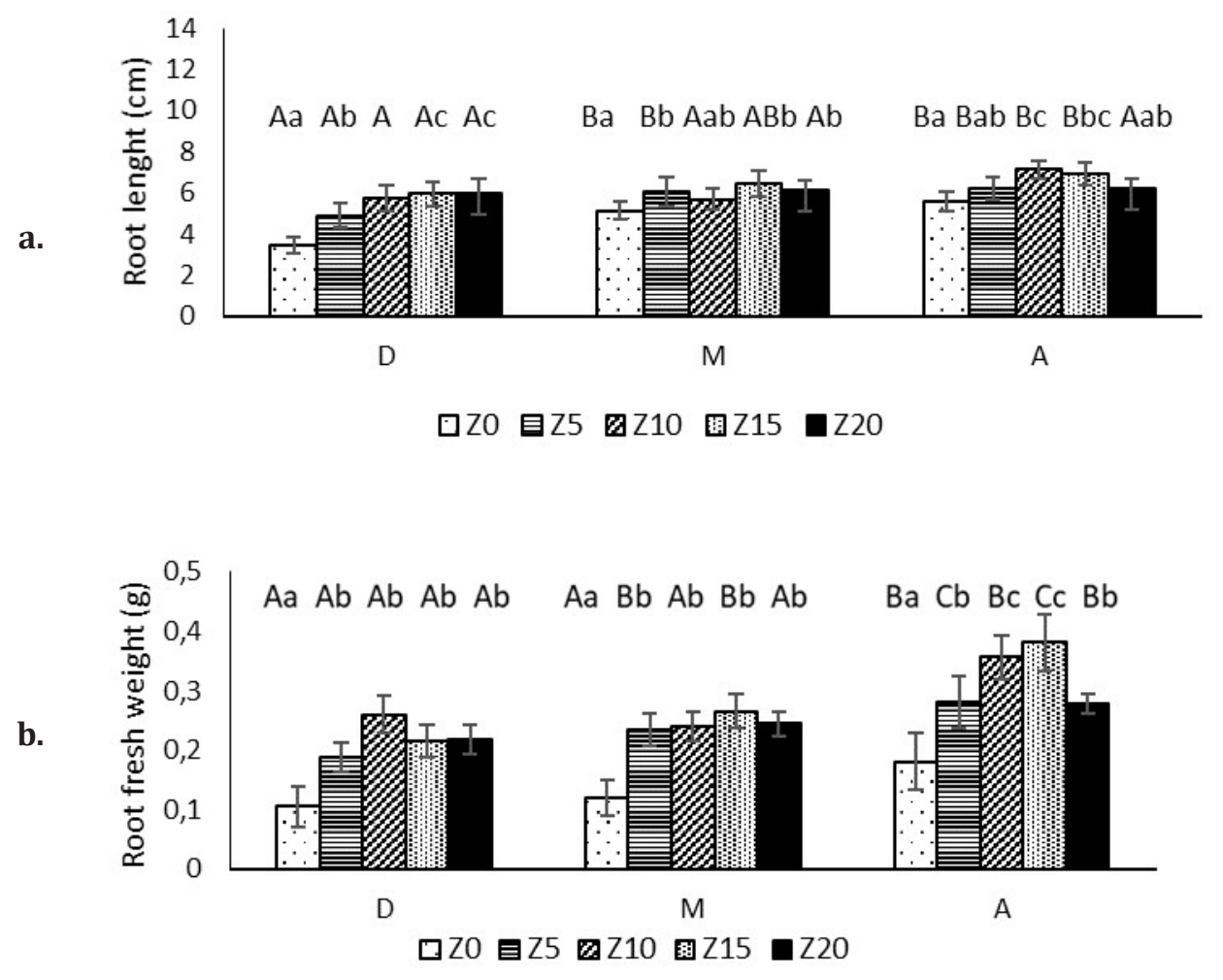

Figure 3. Root length (a) and root fresh weight (b) of cotton seedlings under different SAP rates and irrigation treatments (SAP rates Z0, Z5, Z10, Z15, Z20 and irrigation levels D, M and A are as defined in Fig. 1). 

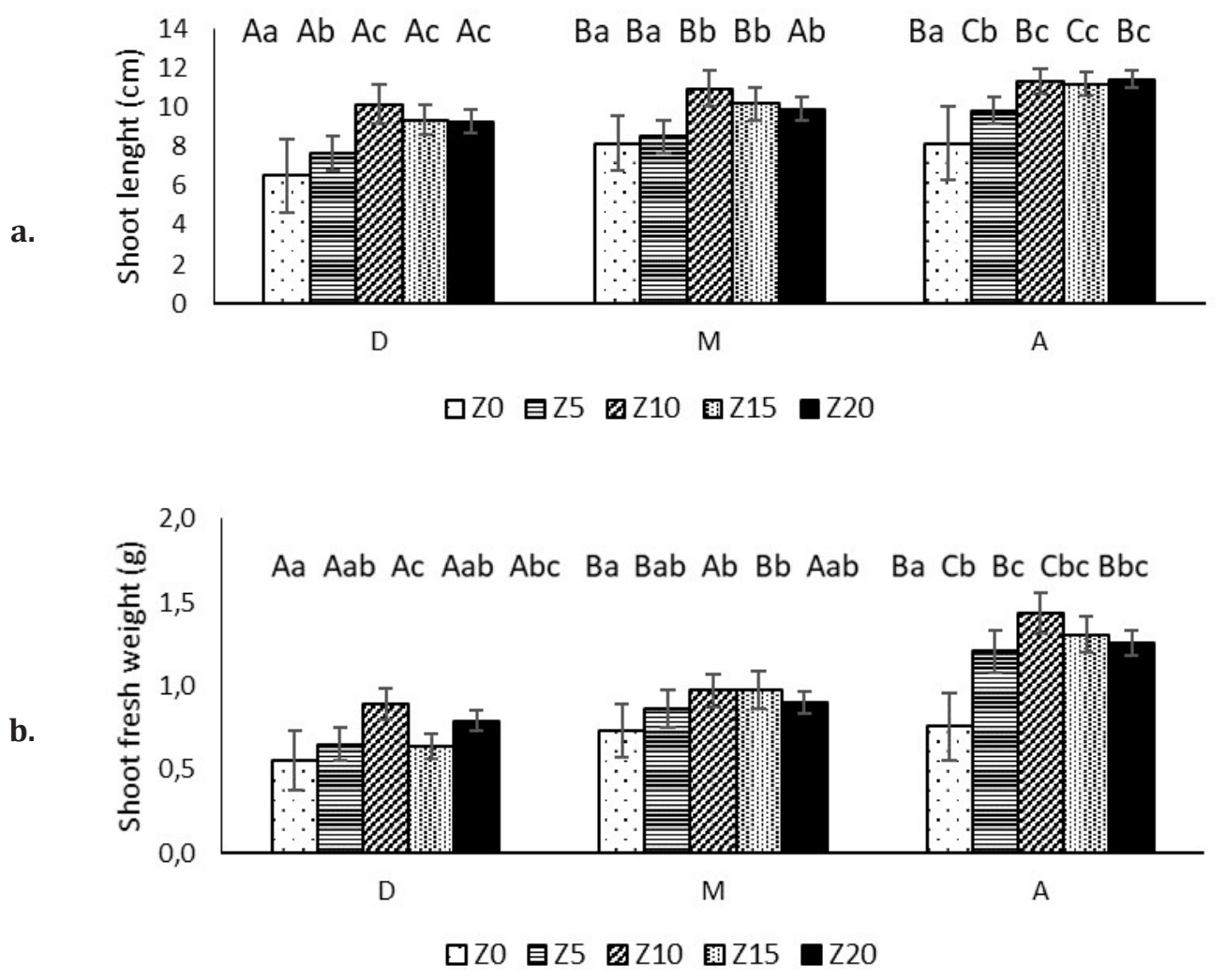

Figure 4. Shoot length (a) and shoot fresh weight (b) of cotton seedlings under different SAP rates and irrigation treatments (SAP rates Z0, Z5, Z10, Z15, Z20 and irrigation levels D, M and A are as defined in Fig. 1).

environments. Superabsorbent polymers can enhance the retention of large quantities of water and nutrients which are released slowly according to the plants' needs, to improve growth under limited water supply (Abobatta, 2019; Yazdani et al., 2007).

\section{Conclusion}

The results of the present study indicated that Zeba ${ }^{\circledR}$ application and irrigation treatments had a significant effect on seedling emergence and growth parameters of cotton. In particular, $Z_{\text {eba }}{ }^{\circledR}$ application exhibited potential to increase moisture conservation and enhance seedling growth of the crop. The addition of superabsorbent polymers as cultural practice will be useful and improve plant establishment under limited water availability conditions.

\section{References}

1. Abobatta W (2018). Impact of hydrogel polymer in agricultural sector. Adv. Agr. Environ. Sci., 1(2): 59-64.

2. Akhter J, Mahmood K, Malik KA, Mardan A, Ahmad M, Iqbal MM (2004). Effects of hydrogel amendment on water storage of sandy loam and loam soils and seedling growth of barley, wheat and chickpea. Plant Soil Eviron., 50(10): 463-469.

3. Bordovsky JP, Cranmer AM, Colaizzi PD, Lamm FR, Evett SR, Howell TA (2012). Investigating strategies to improve crop germination when using SDI. Proceedings of the $24^{\text {th }}$ Annual Central Plains Irrigation Conference, 21-22 February, Kansas, USA, 117-132.

4. Chiorescu E, Clinciu-Radu AR, Chiorescu D, Teliban GC, Robu T (2017). Research on the influence of hydrogels Zeba SP and Terracottem on the development of some aromatic plant species. Res. J. Agric. Sci., 49(4): 385-391.

5. Cranmer AM, Bordovsky JP, Mustian JT, Nesmith DM (2009). Soil amendment and tillage evaluation to improve germination with subsurface drip irrigation. Proceedings of the Beltwide Cotton Conference, 5-8 January, San Antonio, Texas, 411-421.

6. Ellis RH, Roberts EH (1980). Towards a rational basis for testing seed quality. In P.D. Hebblethwaite (Ed.), Seed Production (pp. 605-635). Butterworths, London. 
7. Eneji AE, Islam R, An P, Amalu UC (2013). Nitrate retention and physiological adjustment of maize to soil amendment with superabsorbent polymers. J. Clean. Prod., 52: 474480.

8. Fallahi HR, Taherpour Kalantari R, Aghhavani-Shajadi M, Soltanzadeh MG (2015). Effect of super absorbent polymer and irrigation deficit on water use efficiency, growth and yield of cotton. Not. Sci. Biol., 7(3): 338-344.

9. FAOSTAT (2018). Food and Agricultural Organization of the United Nations. Statistics Database.

10. Guilherme MR, Aouada FA, Fajardo AR, Martins AF, Paulino AT, Davi MFT, Rubira AF, Muniz EC (2015). Superabsorbent hydrogels based on polysaccharides for application in agriculture as soil conditioner and nutrient carrier: a review. Eur. Polym. J., 72: 365-385.

11. Kumar B, Deeba F, Priyadarshi R, Sauraj, Negi YS (2018). Agriculture: Super Absorbent Functional Polymers. In M. Mishra (Ed.), Encyclopedia of polymer applications Vol I (pp. 93-110). CRC Press, USA.

12. Li X, He JZ, Hughes JM, Liu YR, Zheng YM (2014). Effects of super-absorbent polymers on a soil-wheat (Triticum aestivum L.) system in the field. Appl. Soil Ecol., 73: 58-63.

13. Mazen AM, Radwan DEM, Ahmed AF (2015). Growth responses of maize plants cultivated in sandy soil amended by different superabsorbent hydrogels. J. Plant Nutr. 38: 325-337.

14. Nnadi F, Brave C (2011). Environmentally friendly superabsorbent polymers for water conservation in agricultural lands. J. Soil Sci. Environ. Manage., 2(7): 206211.

15. Ngobeni N, Buthelezi N, Mataruka D (2019). Growth and yield response of cotton cultivars to "Zeba" superabsorbent polymer and $\mathrm{N}$-application under dryland conditions. Afr. J. Agric. Res. (in press).

16. Papastylianou P, Argyrokastritis I (2014). Effect of limited drip irrigation regime on yield, yield components, and fiber quality of cotton under Mediterranean conditions. Agric. Water Manag. 142: 127-134.
17. Papastylianou P, Karamanos AJ (2012). Effect of Osmopriming Treatments with Mannitol on Cottonseed Germination Performance under Suboptimal Conditions. Seed Sci. Technol., 40: 248-258.

18. Ranganathan N, Bensingh RJ, Kader MA, Nayak SK (2018). Cellulose-based hydrogels for agricultures. In I.H. Mondal (Ed.), Cellulose-based superabsorbent hydrogels, Polymers and polymeric composites: A reference series (pp. 1-20). Springer, USA.

19. Rasanjali KGAI, de Silva CS, Priyadarshani KDN (2019). Influence of super absorbent polymers (SAPs) on irrigation interval and growth of black pepper (Piper nigrum L.) in nursery management. OUSL Journal 14(1): 7-25.

20. Serena M, Leinauer B, Sallenave R, Schiavon M, Maier B (2012). Turfgrass establishment from polymer-coated seed under saline irrigation. Hortscience, 47(12): 17891794.

21. Tao J, Zhang W, Liang L, Lei Z (2018). Effects of ecofriendly carbohydrate-based superabsorbent polymers on seed germination and seedling growth of maize. R. Soc. Open Sci, 5: 171184.

22. Tsaliki E, Xanthopoulos F, Kechagia U, Leloudis C (2019). Evaluation of germination ability of cotton cultivars (Gossypium hirsutum L.) under artificial stress conditions. Agric. Sci. Pract. 4(1): 4-8.

23. Yazdani F, Allahdadi I, Akbari GA (2007). Impact of superabsorbent polymer on yield and growth analysis of soybean (Glycine max L.) under drought stress conditions. Pak. J. Biol. Sci., 10: 4190-4196.

24. Vizitiu O, Calciu I, Simota C, Pănoiu I (2012). Increasing the plant water availability as an effect of superabsorbents application. Proceedings of Conference: Cea de a XX-a Conferință Naţională de Ştiința Solului, cu participare internaţională, Craiova, Romania, Volume: Agricultura, Montanologie, Cadastru vol. XLII-2012/1.

25. Zohuriaan-Mehr MJ, Kabiri K (2008). Superabsorbent polymer materials: A review. Iran. Polym. J., 17(6): 451477. 